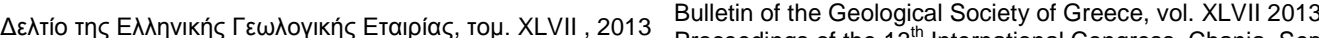
$\triangle 1$ Proceedings of the $13^{\text {th }}$ International Congress, Chania, Sept.

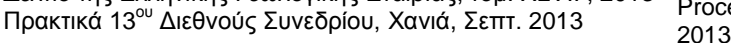

\title{
ASSESSING AREAS OF SLOPE INSTABILITY THROUGH A SPATIAL DECISION SUPPORT SYSTEM
}

\author{
Rozos D. ${ }^{1}$, Tsangaratos P. ${ }^{1}$, Loupasakis C. ${ }^{1}$, Koumantakis I. ${ }^{1}$ and \\ Markantonis K. ${ }^{1}$ \\ ${ }^{1}$ National Technical University of Athens, School of Mining and Metallurgical Engineering, \\ Department of Geological Studies,rozos@metal.ntua.gr,ptsag@metal.ntua.gr, \\ cloupasakis@metal.ntua.gr,koumantakisioannis@gmail.com,markantonis@metal.ntua.gr
}

\begin{abstract}
The purpose of this study was to highlight the analytic power of a Spatial Decision Support System (SDSS) in slope stability problems and to present the process followed during the systematic study of the landslide phenomena manifested in the Chalki village, Korinthos Prefecture, Greece. The mass movements affected the residential area of Chalki village making urgent the need of immediate mitigation measures. The two main objectives of the developed Spatial Decision Support System (SDSS) were to evaluate the landslide susceptibility of the research area and to locate the most suitable areas for addressing investigation schemes and installing landslide monitoring systems.
\end{abstract}

Key words: Landslide susceptibility, Ranking Method, Landslide monitoring system.

\section{Пєрí}

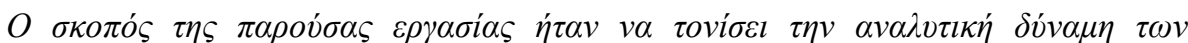

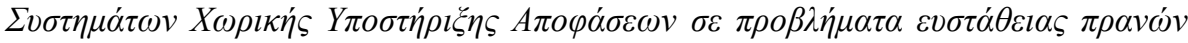

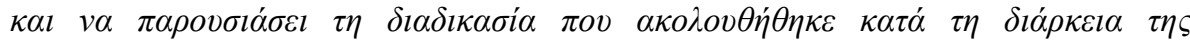

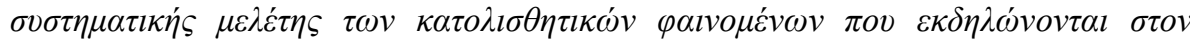

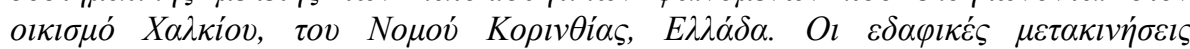

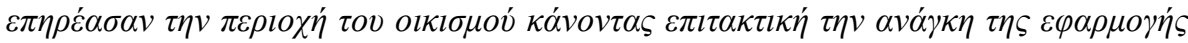

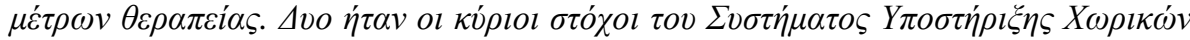

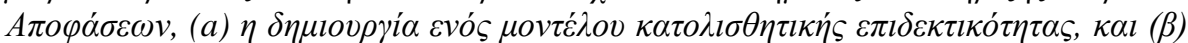

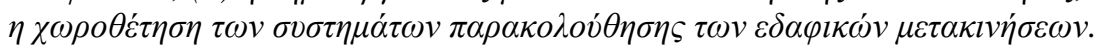

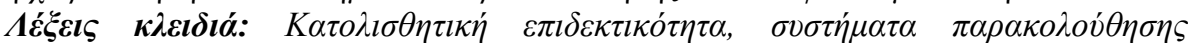
$\varepsilon \delta \alpha \varphi \imath \kappa \omega ́ v ~ \mu \varepsilon \tau \alpha \kappa \imath v \dot{\sigma} \sigma \varepsilon \omega v$.

\section{Introduction}

The Village of Chalki, Korinthos Prefecture, Greece, is being affected by severe mass movements that have disrupted large portions of the urban settlement, since 1950. These phenomena have been occasionally reactivated either as a consequence of human activities or as a consequence of extreme natural events, such as heavy rainfall and seismic activity (Rozos et al., 2012). A number of serious damages on existing buildings, fencing walls, water supply networks as well as on the road infrastructure were recorded in 2003 , after a three years period of increased rainfall. The 
observed mass movements had the form of shallow slope movements (creep) characterized by slow deterioration of the ground that caused serious problems in the region that surrounded the village of Chalki. As reported widely through the literature, landslide phenomena can be managed using a variety of analytic methods depending on the objective and the scale of the study, but also on the available data (Cruden \& Varnes, 1996, Dai et al., 2002, Fell et al., 2008). The deterministic limit equilibrium methods are used for the study of local site conditions, while geomoprhological or multivariate statistical methods are implemented over larger areas (Glade et al., 2005). Regardless the method initialized, the outcomes of a landslide assessment provide useful knowledge about the probability of failure and also serve as guidance in making land use decisions and planning procedures. An appropriate tool that could assist in identifying effective decision calls is a computer model that comprises a decision support system and a geographic information system, referred to as Spatial Decision Support System (SDSS). A Spatial Decision Support System is an interactive, computer-based system designed to assist in decision making while solving a semi-structured spatial problem (Sprague \& Carlson, 1982). Several SDSS for managing slope stability and soil erosion problems have been developed by researchers (Lawrence et al., 1997, Dragan et al., 2003, Barac et al., 2004, De la Rosa et al., 2004, Mickovski et al., 2005). There can also been found several projects that initialize Geographic Information System (GIS) modelling for landslide susceptibility and hazard (Lazzari \& Salvaneschi, 1999, Carrara et al., 1999, Cavallo \& Norese, 2000, Donati \& Turrini, 2002, Rozos et al., 2011), erosion vulnerability (Huang et al., 2003) and environmental vulnerability (Li et al., 2006). Based on recent studies of GIS applications, which model landslide susceptibility, it is established that models need to improve their ability to predict landslides and be more helpful for engineers, policy - makers and developers. They need to be more helpful in the direction of providing the ability to locate appropriate areas to carry out investigation schemes, or to locate areas to install landslide monitoring systems and to implement effective landslide hazard mitigation measures. The present study focused on developing a SDSS within a GIS platform that had two main objectives: (a) the development of a landslide susceptibility model and (b) locating areas for installing landslide monitoring systems. The developed SDSS was evaluated at Chalki village, in the prefecture of Korinthos, Greece.

\section{Materials and Methods}

\subsection{Framework for Producing a Susceptibility Map Through SDSS}

The developed SDSS module consisted of three components: (a) a spatial database management system (SDMS), (b) a set of techniques and methods for enabling specific spatial functions for landslide assessment and (c) a graphical user interface (GUI) to assist users' interaction with the system. The first component, the spatial database management system is the main core of the system. In the ArcGIS platform, the GIS software that is used in this study, the SDMS is a well designed geodatabase. The second component consists of a set of techniques and methods to assess slope stability and landslide hazards, in particular techniques that assist in producing landslide susceptibility models and conduct spatial analysis for locating areas to address landslide monitoring systems. The third component of the developed SDSS module is the GUI that allows interaction between the user's and the system in a graphical and friendly way. The present study focuses on the techniques and methods that are embodied in the SDSS, a brief description of which is given in the following section.

\subsection{Calculating Landslide Susceptibility Index}

Landslide susceptibility is a quantitative or qualitative assessment of classification, volume, and spatial distribution of landslides, which exist or potentially occur in an area. In a landslide susceptibility analysis, time - frame is explicitly not taken into consideration (Corominas et al., 2000, Glade et al., 2005). In the present study the landslide susceptibility index is calculated by applying the weighted linear combination (WLC) method, which is one of the best know and

XLVII, No $3-1845$ 
commonly used methodology in spatial analysis (Malczewski, 1999, Ayalew et al., 2004). The main objective is to estimate the total score an area achieves and thus compiling the landslide susceptibility map. The linear correlation is given by the formula showed in equation 1 .

\section{Equation 1 - Landslide susceptibility index}

$$
L s i=\frac{1}{n} \sum_{i=1}^{n} f_{i} w_{i} * w_{c i j}
$$

where, $\mathrm{L}_{\mathrm{si}}$ is the overall score that represents the landslide susceptibility index, $\mathrm{n}$ the number of factors, $\mathrm{fw}_{\mathrm{i}}$ the weight coefficient of the $\mathrm{i}^{\text {th }}$ factor and $\mathrm{w}_{\mathrm{ci}}$ the weight coefficient of the $\mathrm{j}^{\text {th }}$ class of the $i^{\text {th }}$ factor.

The Ranking Method was utilized to estimate both the weight of importance that each landslide related factor has, and also the weight of susceptibility that each class of each factor has. The Ranking Method is one of the simplest methods for estimating importance weights in a set of criterion, while the most popular procedure for generating numerical weights is the Rank Sum method (Stillwell et al., 1981, Malczewski, 1999). The weights from the Rank Sum method, which also engaged in this study, are calculated according to equation 2.

Equation 2 - weight coefficient using the Rank Sum method

$$
w_{i}=\frac{n-r_{i}+1}{\sum\left(n-r_{k}+1\right)}
$$

where, $w_{i}$ is the normalized weight for the $i^{\text {th }}$ criterion, $n$ is the number of criteria $(k=1,2 \ldots n), r_{i}$ is the rank position of the criterion.

Following the above concept, the landslide susceptibility index is categorized into three classes utilizing natural breaks classification based on accumulative weight and score (Jenks, 1967). The method seeks to minimize each class's average deviation from the class mean, in other words reducing the variance within the class, while maximizing each class's deviation from the means of the other groups, leads to maximizing of the variance between classes (De Smith et al., 2007). To complete the analysis the $\mathrm{L}_{\mathrm{SI}}$ map must be validated. For this purpose, depending on the technique of analysis, a portion or the complete landslide database is overlaid in the form of a layer, known as landslide inventory map. A landslide inventory map indicates the location and, if available, additional information about past and present mass movements characteristics (e.g., type of movements, depth, date, age, degree of activity, magnitude, direction and velocity) that left discrete features in an area (Hansen, 1984, Guzzetti et al., 2000). Statistical directives are then estimated taking account the spatial distribution of the landslide incidence and the zones of susceptibility that have been produced by the model. The approach that this study follows depends on expert knowledge, thus the landslide inventory map is mainly used in the procedure of locating the areas for establishing landslide monitoring systems than for validation reasons.

\subsection{Indentifying Areas to Address Geotechnical Investigation Schemes and to Install Landslide Monitoring Systems}

Landslide hazard mitigation strategies comprise a range of activities including hazard mapping and assessment, real time monitoring and warning systems, protective engineering measures, and also development of public awareness and emergency planning (Savvaidis et al., 2001). It also must be reported that for accurate landslide inventory mapping and analysis of landslide characteristics, aerial photos, geotechnical data and monitoring results should be integrated with field surveys and any other available information. All the above activities have a spatial dimension in which location play a very important role. After contacting a landslide susceptibility analysis, the next phase is to locate the areas for installing landslide monitoring systems. Both of these actions are very 
significant in a landslide assessment and could be thought as a spatial decision analysis problem, defined as how to maximize the information and data that one can get by choosing among several spatial alternative schemes. The developed SDSS allows inputting layers of information, e.g. infrastructure network, urban areas and land use cover, etc. and also utilizing specific spatial functions the output of which could be useful during the decision analysis phase. It also allows manipulating data that concern damages reported on structures and infrastructure or the agriculture facilities, within a spatial framework. By this procedure the SDSS provide a metric function with which the user assigns priority values to the entire area. Another important aspect that the SDSS provides is the ability to map the land use characteristics of the surrounding area and assign to the different types, values of significance according to expert judgment. As an example, it is obvious that in a landslide hazard assessment urban areas are more significant than areas located in a forest, in the sense that if a landslide incidence evolve in an urban area, the casualties and disruption would be much more important. In the same way, areas that had previously reported as been affected have priority against non-affected areas, since reactivation of the mass movement may be possible. As for the landslide monitoring systems they can be classified as remote sensing or satellite techniques, photogrammetric techniques, geodetic or observational techniques, and geotechnical or instrumentation or physical techniques (Gili et al., 2000, Corominas et al., 2000, Savvaidis et al., 2001). For the purpose of the study, geotechnical techniques were under consideration. Specifically, geotechnical techniques involve the installation and monitoring of inclinometers, extensometers, piezometers, geophones, tiltmeters and crack meters. The type of instrument also defines the location of installation. As for example, inclinometers are installed in boreholes drilled within the landslide mass. In the case where the available instruments are few and a decision should be made of where to be installed, the proximity to urban settlements plays a role in choosing an alternative. The closer the urban settlements, the more critical the information extracted are. Within this framework, distance functions are applied to each layer of information and each zone is assigned a value of significance. The final process is to combine the landslide susceptibility map with the findings of the above analysis and provide a decision upon the most suitable area for installing landslide monitoring systems.

\section{The Case Study}

\subsection{Geological Settings}

The urban settlement of Chalki village $\left(37^{\circ} 5240,22^{\circ} 4340\right)$ is part of the municipality of Vochas located approximately $3 \mathrm{~km}$ southwest of the village of Soulinari. The village is located on gentle slopes northwest of Mount Foukas which forms the eastern slopes of the basin of Zapantis having altitude values ranging from 240 to 320 meters, Figure 1 .

The geological formations that cover the wider research area consist of neogene sediments, pliopleistocene deposits (conglomerates, clayey marls, calcite marls) and diluvial conglomerates. These formations are covered in places by a thin weathering mantle that has been created by erosion and alteration process (Figure 1). The most dominant formations that cover the research area are the clayey marls and the calcite marls. The clayey marls are characterized as easily weathered, semi-coherent and with varying permeability. Their water content increases significant upon wetting, decreasing its geomechanical characteristics. The calcite marls appear to be more resistance to weathering process and characterized as hard to stiff marl formation with very low permeability. The field survey and the study of aerial photos, revealed the presence of two main set of tectonic lineaments with directions SW - NE and NNW - SSE respectively that have altered the geomorphologic characteristics of the area. As for the seismic activity, the seismicity of the area is indirectly influenced by the seismic epicentres of the Corinth Gulf and therefore the values of the peak ground acceleration are expected to be high (Koumantakis et al., 2005). Finally, the mean annual precipitation reaches $538 \mathrm{~mm}$ with $72.5 \%$ falling between the months of November and March.

$\underline{\text { XLVII, No } 3-1847}$ 

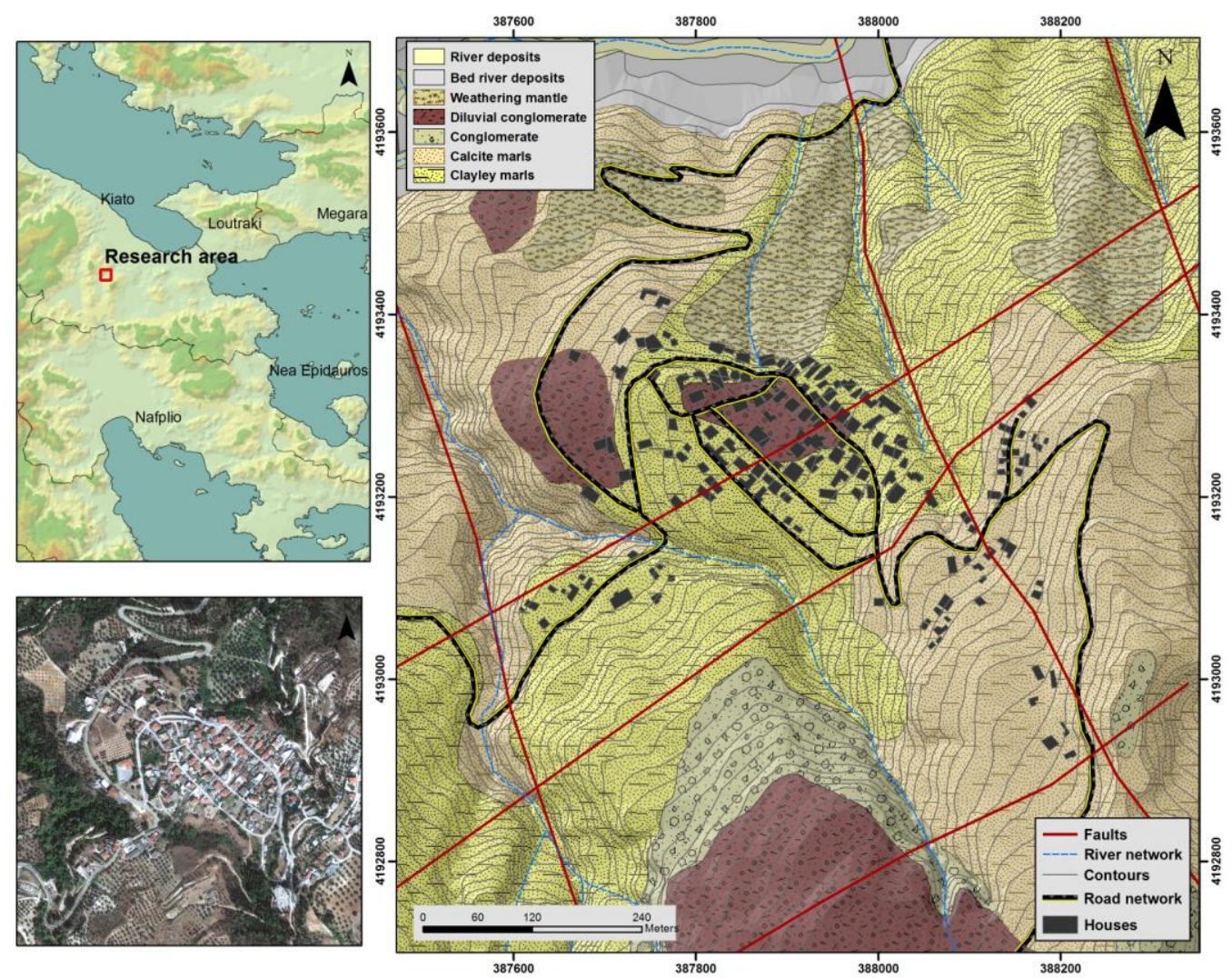

Figure 1 - The geological setting of the study area.

\subsection{Selecting the Appropriate Factors and Assessing the Weight Coefficients}

The factors that appear to influence the manifestation of a landslide in a site could be distinguished into causative and triggering factors. Causative factors actually determine the favourable settings that may cause a landslide, while triggering factors determine the temporal characteristics of a landslide incidence. Seismic activity, intensive rainfall and human activities are thought to be the most common triggering factors. However, the usage of these types of data that appear to be unpredictable and vary in time is limited in landslide assessments (Guzzetti et al., 2000). On the other hand the causative factors are easily defined and used extensively in landslide assessments (Glade et al., 2005). It is well know that lithology plays a crucial role in controlling instability. The reclassified map had three classes based on different susceptibilities to landslide and accordingly are assigned a higher or lower ranking value (Table 1). The river deposits, bed river deposits and the weathering mantle are classified into the most susceptible class, eguA. The diluvial conglomerate, conglomerate and clayey marl formations have been classified into class eguB, that represent medium susceptible formations, while the calcite marls are classified as the less susceptible class, eguC.

As reported in the literature, geo-morphological settings can affect the landslide occurrence. Specifically, the dynamic behaviour of a landslide event has close affinity to the slope values (Carrara, 1983, Maharaj, 1993). Slope controls the subsurface flow velocity after rainfalls, the runoff rate and the soil water content. As slope value increases shear stress in unconsolidated soil cover increases as well. The raster format file was obtained from the DEM file. In the reclassified map, slope values were subdivided into three classes: (a) Gentle slopes $\left(<13^{\circ}\right)$, Moderate steep slopes $\left(13^{\circ}-27^{\circ}\right)$, Steep slopes $\left(>27^{\circ}\right)$. 
Table 1 - Assessing weights to each class of each factor.

\begin{tabular}{|l|l|l|l|}
\hline \multicolumn{1}{|c|}{ Factors } & \multicolumn{1}{c|}{ Classes } & \multicolumn{1}{c|}{$\begin{array}{c}\text { Straight } \\
\text { rank }\end{array}$} & $\begin{array}{c}\text { Normalized } \\
\text { weight }\end{array}$ \\
\hline A. Eng. Geol. Units & & $\mathbf{1}$ & $\mathbf{0 . 3 3 3 4}$ \\
\hline River deposits & eguA & 1 & 0.50 \\
\hline Bed River deposits & eguA & 1 & 0.50 \\
\hline Weathering mantle & eguA & 1 & 0.50 \\
\hline Diluvial conglomerates & eguB & 2 & 0.3334 \\
\hline Conglomerate & eguB & 2 & 0.3334 \\
\hline Calcite marls & eguC & 3 & 0.1667 \\
\hline Clayey marls & eguB & 2 & 0.3334 \\
\hline B. Slope & & $\mathbf{4}$ & $\mathbf{0 . 1 3 3 4}$ \\
\hline$\left(0^{\circ}-13^{\circ}\right)$ & slpA & 1 & 0.50 \\
\hline$\left(13^{\circ}-27^{\circ}\right)$ & slpB & 2 & 0.3334 \\
\hline$>27^{\circ}$ & slpC & 3 & 0.1667 \\
\hline C. Aspect & & $\mathbf{2}$ & $\mathbf{0 . 2 6 6 7}$ \\
\hline N-NE & aspA & 1 & 0.50 \\
\hline E-W & aspB & 2 & 0.3334 \\
\hline S-SW & aspC & 3 & 0.1667 \\
\hline D. Proximity to river network & & $\mathbf{3}$ & $\mathbf{0 . 2 0}$ \\
\hline$<50 \mathrm{~m}$ & rvrA & 1 & 0.6667 \\
\hline$>50 \mathrm{~m}$ & rvrB & 2 & 0.3334 \\
\hline E. Proximity to tectonic lineaments & & $\mathbf{5}$ & $\mathbf{0 . 0 6 6 7}$ \\
\hline$<50 \mathrm{~m}$ & tectA & 1 & 0.6667 \\
\hline$>50 \mathrm{~m}$ & tectB & 2 & 0.3334 \\
\hline
\end{tabular}

Also, the aspect of the surface contributes to the overall slope instability in the same way the slope factor does. It's known that certain orientations are associated with increased snow concentration or intense erosion and weathering processes. It also affects indirectly other factors such as the flora distribution, the degree of saturation and evaportranspiration of the slopes and also the soil thickness. It is general considered that $\mathrm{N}$ and $\mathrm{NW}$ - facing slopes are the most favourable to landslide due to their shadier and colder conditions that favour the accumulation and preservation of soil moisture (Guzzetti et al., 1999). The frequency of landslides is expected to be higher on $\mathrm{N}$ and NW facing slopes, due to water accumulation and lower on east - facing and SE facing slopes as a result of decreased wetness. The aspect raster file has been divided into three classes, namely aspA, aspB and aspC. In the research area those orientations are the N-NE, E-W and S - SW. Another factor of great importance is the proximity to the stream network. An area closer to the river path has higher water content and hence may exhibit higher susceptibility to landslide phenomena. The thematic layer of proximity to river network was generated using a buffer around the streams. It was classified into two distance classes, (a) $<50 \mathrm{~m}$ from streams, (b) greater than 50 $\mathrm{m}$. As the distance from the network increases the landslide susceptibility decreases. Hence, the classes of the buffered proximity to river network map have been assigned rating values in decreasing order based on the distance from the streams. Proximity of landslide incidence to thrust and fault zones is consequence of the contacts between overlaying more permeable rocks and underlying less permeable or impermeable formations resulting in abundance of springs and also sheared zones of weakened and fracture rocks. On the vectorized layer a distance function was applied to define two buffer zones along the structural discontinuities, a zone less than $50 \mathrm{~m}$ from 
tectonic features and a zone greater than $50 \mathrm{~m}$. As the distance from the tectonic lineaments increased landslide susceptibility decreases. Hence, the classes of the buffered proximity to tectonic features were rated in a decreasing order according to their distance to thrust and fault zones. Table 1 shows both the weight of importance that each factor has, and also the weight of susceptibility that each class of each factor has as they were calculated by the Rank Sum method.

\subsection{Producing the Landslide Susceptibility Index Map}

The landslide susceptibility index values are varying within the range of 0 and 1 . The higher the value the more susceptible the area is. However, the $\mathrm{L}_{\mathrm{SI}}$ map was reclassified into three categories namely, "low", "moderate" and "high", as shown in Figure 2. Applying ArcMap Field Calculator and the Calculate Geometry dialog box, it was found that about $43 \%$ of the research area is characterized as low susceptible, $35 \%$ as medium susceptible and $22 \%$ as high susceptible. The $\mathrm{L}_{\mathrm{SI}}$ map shows that the high susceptible zones were found mainly in areas where clayey marl outcrop, on moderate to steep slopes and near streams and fault zones. It also shows that only a small portion of the urban area is appreciated as high susceptible. It must be noted that these location have been reported of having the most serious damages on buildings, fencing walls, water supply networks as well as on the road infrastructure.

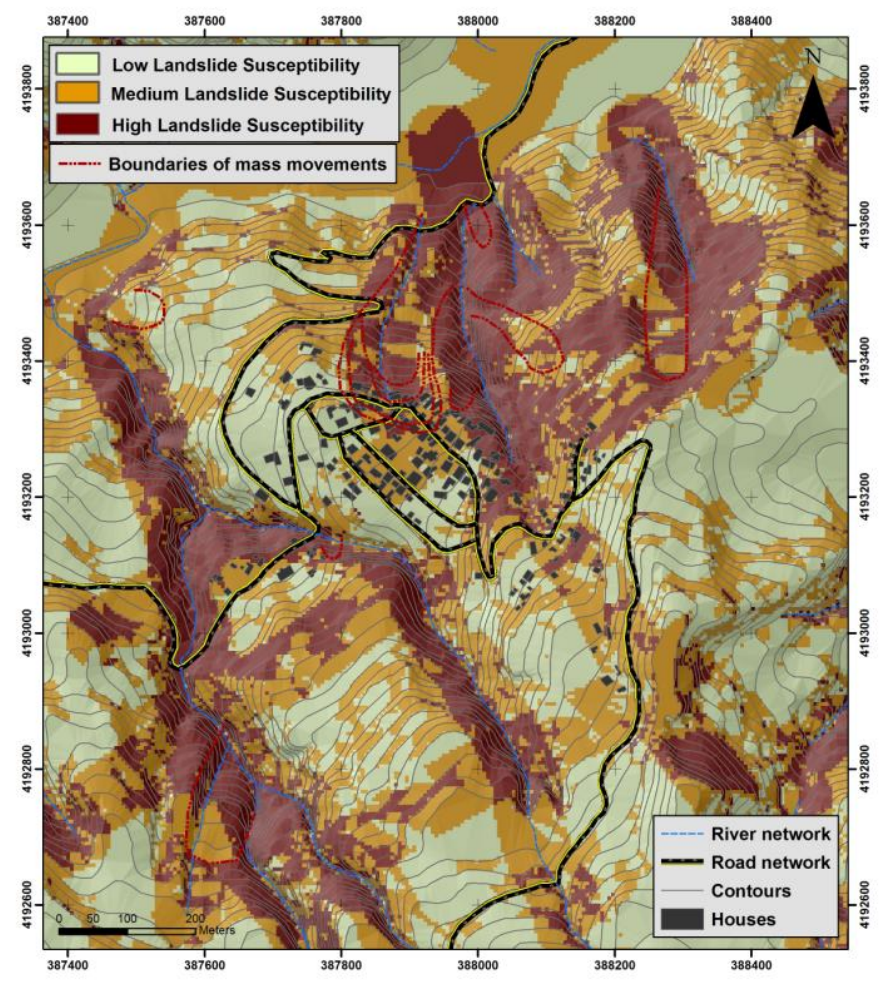

Figure 2 - The landslide susceptibility map and the overlaid landslide inventory map.

\subsection{Locating Areas to Apply Systems and Techniques for Monitoring Mass Movements}

Three different geotechnical techniques for landslide monitoring where selected: (a) inclinometers, (b) piezometers, and (c) tile-tale crack meters. According to the methodology, on the vectorized landslide inventory map, a distance function was applied to define a buffer zone, $50 \mathrm{~m}$ from each landslide features, assigning to those zones high value of significance (Figure 3). Within those zones inclinometers should be more appropriate to install.

XLVII, No $3-1850$ 
As already mentioned the exact location is a decision-making problem and other considerations should be taken into account in order to evaluate the alternatives. The most critical consideration is the proximity to urban settlements. To obtain the proximity value, the Calculate Geometry dialog box was enabled in order to find the centroid of the polygon that represents the urban settlements. Then, the distance between the centroid and each landslide buffer zone is calculated (Figure 3).

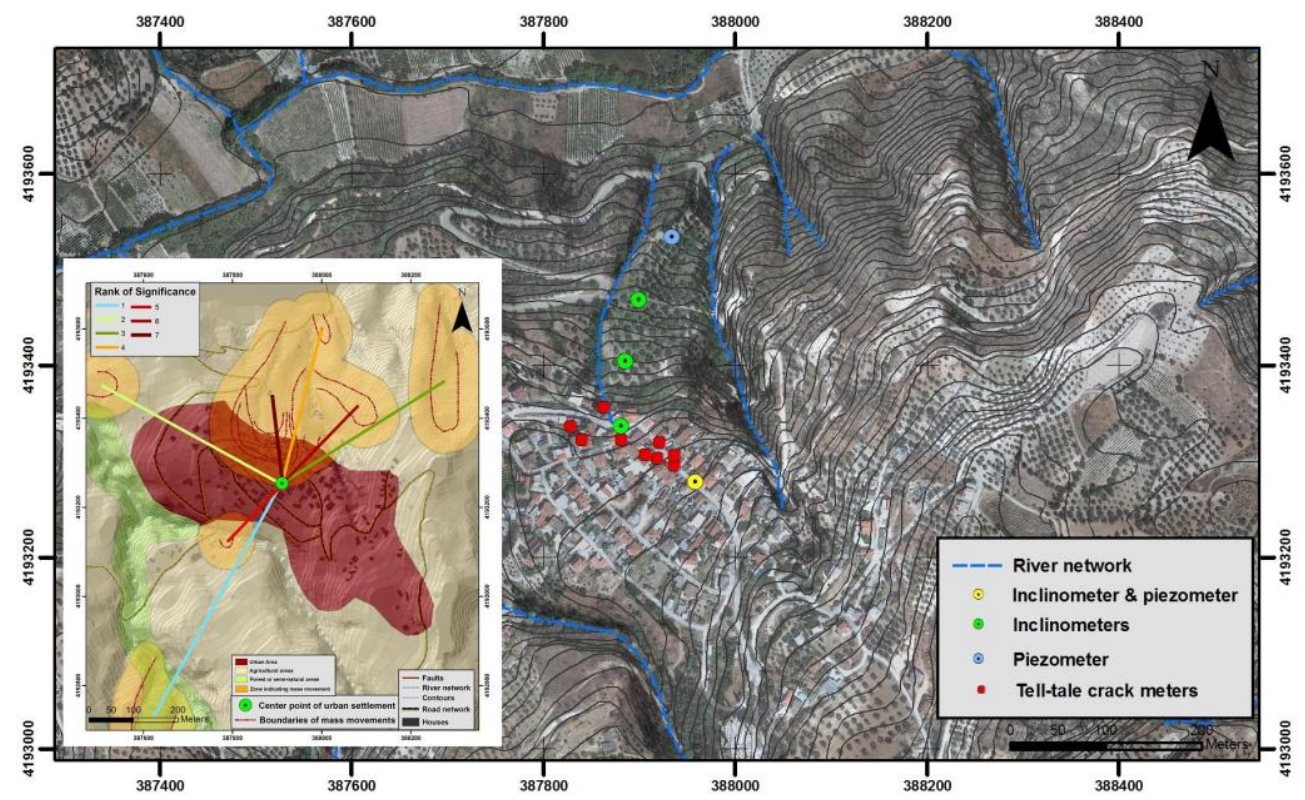

Figure 3 - The locations of the proposed landslide monitoring system.

The piezometers measure the fluctuations of the ground water table and eventually the pore water pressure within a geological structure. So, they give an indication of the build up of stresses and strains within a ground mass. As previously referred, the landslide zones are the most suitable for installing the piezometers and the exact location is found applying the same procedure. Finally, the installation of the tell-tale crack meters in areas where damages on building and wall fences are reported is the most common approach.

\section{Discussion and Conclusions}

The shape and size of mass movements vary because of the complex interrelationship that arises among several preparatory and triggering factors (Coates, 1977). Mass movements may be controlled by the topographic factor, such as considering the inclination, orientation and shape of the slope, the lithologic ones such as physical characteristics and mechanical properties, the geological structure, considering the tectonic features, the hillslope hydrologic factors such as pore pressure, or a combination of all these factors. The study indicated that the last serious reactivation of the observed mass movements had as a triggering factor the intensive rainfall that have been recorded in the year 2003. It also concluded that the type of the lithological units found in the area, specifically the Plio-Pleistocene clayey marl horizons and the underlying calcite marls were responsible for the evolution of mass movements. In addition, the weathering action of the surface water and the raising of the water table could alter the physical and mechanical properties of the formations. Failure occurs, when the driving forces that create movement exceed the resisting forces of the material, while triggering factors may increase the shear stress or decrease the shearing resistance of the material or enable both of these mechanisms. The main objective of the developed SDSS was to be a useful tool in manipulating data and information that are collected

XLVII, No 3 - 1851 
from the analytic observation and study of the area susceptible to landslide manifestation. Applying the Rank Sum method the weight values of the landslide related factors were obtained and by implementing WLC method the landslide susceptibility index was estimated for each cell of the entire research area. The produced landslide susceptibility map was reclassified into three landslide susceptibility zones that indicated that small portions of the urban settlement are in the high landslide susceptibly zone. The main landslide monitoring systems that were proposed for installation in the area included (a) a number of inclinometers for measuring deep displacements, (b) a number of tell-tale crack meters, to measure the surface movements and (c) piezometers, to monitor the fluctuation of groundwater level. There exact placement location was found within the developed SDSS by applying spatial functions and assigning in the entire area values of significance. The outcomes of the study maximized the information that was provided and helped in the direction of defining the surface of displacement.

\section{References}

Ayalew L., Yamagishi H. and Ugawa N. 2004. Landslide susceptibility mapping using GIS-based weighted linear combination, the case in Tsugawa area of Agano River, Niigata Prefecture, Japan, Landslides 1, 73-81.

Barac A., Kellner K. and De Klerk N. 2004. Land user participation in developing a computerized decision support system for combating desertification, Environmental Monitor and Assessment, 99, 223-231.

Carrara A. 1983. Multivariate models for landslide hazard evaluation, Mathematical Geology, 15 (3), 403-426. doi:10.1007/BF01031290.

Carrara A., Guzzetti F., Cardinali M. and Reichenbach P. 1999. Use of GIS technology in the prediction and monitoring of landslide hazard, Natural Hazards 20, 117-135.

Cavallo A. and Norese M. F. 2000. GIS and multi-criteria analysis to evaluate and map erosion and landslide hazards, Informatica, 12, 25-44.

Coates D. R. 1977. Landslide Perspectives, in Coates, D. R. (ed.), Landslides, Reviews in Engineering Geology, Vol. III, Geological Society of America, Boulder, Colorado, 3-28.

Corominas J., Moya J., Lloret A., Gili J.A., Angeli M.G., Pasuto A. and Silvano S. 2000. Measurement of Landslide Displacements using a Wire Extensometer, Engineering Geology, 55, 149-166.

Cruden D. M. and Varnes D. J. 1996. Landslide types and processes, in: Turner A.K.; Shuster R.L. (eds) Landslides: Investigation and Mitigation. Transp Res Board, Spec Rep, 247, 36-75.

Dai F.C., Lee C.F. and Ngai Y.Y. 2002. Landslide risk assessment and management: an overview, Engineering Geology, 64 (1), 65-87.

De la Rosa D., Mayol F., Diaz-Pereira E., Fernandez M. and de la Rosa D., 2004. A land evaluation decision support system (MicroLEIS DSS) for agricultural soil protection, Environmental Modelling \& Software, 19, 929-942.

De Smith M. J., Goodchild M. F. and Longley P.A. 2007. Geospatial Analysis: A comprehensive guide to principles, techniques, and software tools (2nd Edition) Leicester, UK. Matador Publishing Ltd.

Dragan M., Feoli E., Fernetti M. and Zerihun W. 2003. Application of a spatial decision support system (SDSS) to reduce soil erosion in northern Ethiopia, Environmental Modelling \& Software, 18, 861-868.

Donati L. and Turrini M.C. 2002. An objective method to rank, the importance of the factors predisposing to landslides with the GIS methodology: application to an area of the Apennines (Valnerina; Perugia, Italy), Engineering Geology, 63, 277-289.

Fell R., Corominas J., Bonnard C., Cascini L., Leroi E. and Savage W.Z. 2008. Guidelines for landslide susceptibility, hazard and risk zoning for land use planning, Engineering Geology, 102 (3-4), 85-98.

Gili J.A., Corominas J. and Rius J. 2000. Using Global Positioning System Techniques in Landslide Monitoring, Engineering Geology, 55, 167-192.

XLVII, No $3-1852$ 
Glade T., Anderson M. and Crozier M.J. 2005. Landslide Hazard and Risk, John Wiley \& Sons, Ltd., Chichester, England, 802pp.

Guzzetti, F. Cardinali M., Reichenbach P. and Carrara A. 2000. Comparing landslide maps: a case study in the upper Tiber River Basin, Central Italy, Environmental Management, 25(3), 247-363.

Guzzetti F., Carrara A., Cardinali M. and Reichenbach P. 1999. Landslide hazard evaluation: a review of current techniques and their application in a multi-scale study, Central Italy, Geomorphology, 31, 181-216.

Hansen A. 1984. Strategies for classification of landslides, in: Brunsden, D., Prior, D.B. (Eds.), Slope Instability. Wiley, New York, 1-26.

Huang Y.F., Chen X., Huang G.H., Chen B., Zeng G.M., Li J.B. and Xia J. 2003. GIS-based distributed model for simulating runoff and sediment load in the Malian River Basin, Hydrobiologia, 494, 127-134.

Jenks F. G. 1967. The Data Model Concept in Statistical Mapping, International Yearbook of Cartography, 7, 186-190.

Koumantakis I., Rozos D., Markantonis K., Tsangaratos P., 2005. Final technical survey "Study of Landslide phenomena in Chalki, Korinthos. School of Mining and Metallurgical Engineering, Laboratory of Engineering Geology and Hydrogeology, pp 62.

Lawrence P.A., Stone J.J., Heilman P. and Lane L.J., 1997. Using measured data and expert opinion in a multiple objective decision support system for semiarid rangelands, Transactions of the ASABE, 40(6), 1589-1597.

Lazzari M. and Salvaneschi P., 1999. Embedding a geeographic information system in a decision support system for landslide hazard monitoring, Natural Hazards, 20, 185-195.

Li A.N., Wang A.S., Liang S.L. and Zhou W.C. 2006. Eco-environmental vulnerability evaluation in mountainous region using remote sensing and GIS - A case study in the upper reaches of Minjiang River, China, Ecological Modelling, 192, 175-187.

Maharaj R.J. 1993. Landslide processes and landslide susceptibility analysis from an upland watershed: a case study from St. Andrew, Jamaica, West Indies. Eng Geol, 34, 53-79.

Malczewski J. 1999. GIS and Multicriteria Decision Analysis, (John Wiley and Sons, New York, 1999).

Mickovski S.B., Stokes A. and van Beek L.P.H. 2005. A decision support tool for windthrow hazard assessment and prevention, Forest Ecology and Management, 216, 64-76.

Rozos D. Bathrellos D. G. and Skilodimou D. H. 2011. Comparison of the implementation of Rock Engineering System (RES) and Analytic Hierarchy Process (AHP) methods, based on landslide susceptibility maps, compiled in GIS environment. A case study from the Eastern Achaia County of Peloponnesus, Greece, Environmental Earth Sciences, 63(1), 49-63.

Rozos D., Loupasakis, C., Koumantakis, J., Tsangaratos, P. and Markantonis, K., 2012. Remediating Mass Movements induced by Water, in Urban Environments - an example from Chalki Village, Peloponnese, Greece. EGU General Assembly 2012, Austria, pp.6492.

Savvaidis P., Lakakis, K. and Zeimpekis A. 2001. Monitoring Ground Displacements at a National Highway Project: The Case of "Egnatia Odos" in Greece. Proceedings of IAG Workshop "Monitoring of Constructions and Local Geodynamic Process", Wuhan University, China.

Sprague R. H. and Carlson E. D. 1982. Building effective decision support systems, Englewood Cliffs N.J., Prentice-Hall., pp.329.

Stillwell W.G., Seaver D.A. and Edwards W. 1981. A comparison of weight approximation techniques in multi-attribute utility decision making. Organizational Behavior and Human Performance, 28, 62-77. 